\title{
SISTEM JARINGAN PERPIPAAN AIR LIMBAH INDUSTRI KERUPUK KULIT SECARA KOMUNAL (STUDI KASUS PADA SENTRA INDUSTRI KERUPUK KULIT DUSUN CEGOKAN, DESA WONOLELO, KECAMATAN PLERET, KABUPATEN BANTUL) \\ ${ }^{1,2,3}$ Sri Hastutiningrum ${ }^{1}$, Hadi Prasetyo Suseno ${ }^{2}$, Rahmat Ramadhan Topo ${ }^{3}$ \\ Jurusan Teknik Lingkungan, Institut Sains \& Teknologi AKPRIND Yogyakarta \\ Email ${ }^{1}$ hastuti19@akprind.ac.id, ${ }^{2} \mathrm{hp}$ suseno@akprind.ac.id, \\ ${ }^{3}$ rahmatramadhan9801@gmail.com
}

Masuk: 17 Januari 2021, Revisi masuk: 23 Februari 2021, Diterima: 3 Agustus 2021

\section{ABSTRACT}

In Cegokan in Wonolelo Village, Pleret District, Bantul Regency, there are 11 home-made industries that produce leather cracker (krecek) every day by consuming \pm 2 quintals of buffalo and cow skin as raw materials/day. The industries also produce waste 16,438 m3 / day. The wastewater was discharged into rivers without any wastewater treatment process. Some industries have not yet had a piping system to distribute the waste they produce. The purpose of this research was to get a wastewater Piping System planning in order to solve this problem. The planning stage of the wastewater piping system includes planning the piping system, collecting topographic data, calculating the pipe diameter, calculating the dimensions of the control tub, designing the area map image, industrial location, pipeline, and calculating the required budget plan. The wastewater piping system is planned by gravity. This type of pipe is designed for PVC pipe, type AW, with a connection pipe diameter of 2.5 inches, the main pipe is 3 inches in diameter with a main pipe length of $867 \mathrm{~m}$. The control body is designed in the form of a square with 7 tub units with the following dimensions : 5 control units for 1 industry (length $=0.4 \mathrm{~m}$, width $=0.4 \mathrm{~m}$, height $=0.4 \mathrm{~m}$ ), 1 tub for 2 industries (length $=0.48 \mathrm{~m}$, width $=0.48 \mathrm{~m}$, height $=0.48 \mathrm{~m}$ ), one unit of control body for 4 industries (length $=0.6 \mathrm{~m}$, width $=0.6 \mathrm{~m}$, height $=0.6 \mathrm{~m}$ ).

\section{INTISARI}

Dusun Cegokan, Desa Wonolelo, Kecamatan Pleret, Kabupaten Bantul terdapat 11 industri kerupuk kulit (krecek) rumahan yang melakukan produksi hampir setiap hari dengan menghabiskan bahan baku berupa kulit kerbau maupun sapi sebanyak $\pm 2 \mathrm{kwintal} / \mathrm{hari}$, dan menghasilkan limbah rata-rata sebesar $16,438 \mathrm{~m}^{3} / \mathrm{hari}$. Air limbah yang dihasilkan dibuang ke sungai tanpa dilakukan proses pengolahan air limbah. Beberapa industri belum mempunyai sistem perpipaan untuk menyalurkan limbah yang dihasilkan. Tujuan penelitian ini adalah untuk mendapatkan sebuah perencanaan Sistem Perpipaan Air Limbah untuk mengatasi permasalahan tersebut.

Tahap perencanaan sistem perpipaan air limbah meliputi perencanaan sistem perpipaan, pengambilan data kondisi topografi, perhitungan diameter pipa, perhitungan dimensi bak kontrol, merancang gambar peta wilayah, lokasi industri, jalur pipa, serta menghitung rencana anggaran biaya yang diperlukan.

Sistem perpipaan air limbah direncanakan secara gravitasi. Jenis pipa direncanakan pipa PVC tipe AW dengan diameter pipa sambungan 2,5 inci, pipa utama berdiameter 3 inci dengan panjang pipa utama $867 \mathrm{~m}$. Bak kontrol direncanakan berbentuk persegi berjumlah 7 unit bak dengan dimensi meliputi: Bak kontrol untuk 1 industri berjumlah 5 unit (panjang $=0,4$ $\mathrm{m}$, lebar $=0,4 \mathrm{~m}$, tinggi $=0,4 \mathrm{~m}$ ). Bak untuk 2 industri berjumlah 1 unit (panjang $=0,48 \mathrm{~m}$, lebar $=0,48 \mathrm{~m}$, tinggi $=0,48 \mathrm{~m}$ ). Bak kontrol untuk 4 industri berjumlah 1 unit (panjang $=0,6$ $\mathrm{m}$, lebar $=0,6 \mathrm{~m}$, tinggi $=0,6 \mathrm{~m}$ ).

Kata kunci : pra-rancangan, perpipaan, sistem jaringan. 


\section{PENDAHULUAN}

Kabupaten Bantul merupakan salah satu daerah yang mempunyai produk makanan yang cukup banyak dan beraneka ragam jenisnya. Produk makanan penunjang yang cukup terkenal di Kabupaten Bantul yaitu krecek (kerupuk kulit). Kerupuk kulit selalu dibutuhkan dalam keseharian masyarakat Jawa, sehingga produksinya akan terus dilakukan guna mencukupi kebutuhan ataupun permintaan pasar yang semakin tinggi. Keberadaan industri kecil krecek di Kecamatan Pleret Kabupaten Bantul ini tergolong sudah lama. Namun, dalam perjalanannya mengalami pasang surut dari segi jumlah pengusaha krecek yang berada di daerah tersebut. Dari kecamatan tersebut, terdapat dua kelurahan yang merupakan sentra industri krecek yaitu Desa Segoroyoso dan Desa Wonolelo (Anonim, 2019).

Sama halnya dengan yang terjadi di Dusun Cegokan, Desa Wonolelo yang merupakan sentra home industry kerupuk kulit yang setiap harinya memproduksi 1 kwintal kulit sapi dan/atau kerbau per rumah menjadi kerupuk kulit yang siap dipasarkan. Dari belasan industri yang ada, mereka banyak menyuplai kerupuk kulit ke beberapa kabupaten/kota di Jawa Tengah (Wonosobo, Purworejo, Solo) bahkan sampai ke Jawa Timur (Malang). Dalam prosesnya, pembuatan kerupuk kulit akan menggunakan banyak air, sehingga limbah cair yang dihasilkan pun juga cukup banyak karena terdapat 11 home industry yang berada di daerah tersebut (Anonim, 2019).

Berdasarkan isu lingkungan dari warga setempat, air hasil proses pencucian dan perendaman dari kegiatan tersebut langsung dibuang ke badan air tanpa melalui pengolahan sebelumnya sehingga menimbulkan bau yang tidak sedap dan membuat tanaman di persawahan setempat (padi) menguning bahkan mati apabila air tersebut langsung masuk ke persawahan. Secara kasat mata limbah baru yang dihasilkan berwarna putih kecoklatan dan berminyak yang kemudian akan berubah menjadi coklat kehitaman apabila sudah lebih dari satu hari dan baunya akan sangat menyengat (Anonim, 2019).

Kondisi topografi yang relatif tinggi daripada daerah di bawahnya yang berada dalam satu wilayah kelurahan dan kecamatan, maka akan membuat limbah yang terbentuk mencemari badan air maupun perairan yang ada di bawahnya mengikuti aliran sungai yang ada. Menurut pemerintah setempat, jumlah warga yang berada di Kelurahan Wonolelo sejumlah 6047 warga yang terdiri dari 2971 laki-laki dan 3076 perempuan yang kemudian akan terkena dampak apabila limbah tersebut tidak diolah (Anonim, 2019).

Dengan demikian, Instalasi Pengolahan Air Limbah (IPAL) komunal industri menjadi solusi terbaik sehingga air limbah tidak langsung terakumulasi di dalam lingkungan serta tidak terlalu memberatkan suatu industri saja. Ketersediaan IPAL sangat dibutuhkan, sehingga komponen-komponen penunjang IPAL komunal seperti sistem jaringan perpipaan diperlukan sebagai sistem penyaluran air limbah dari sumber penghasil air limbah menuju IPAL. Sistem perpipaan ini diperlukan untuk pengaliran dan pengolahan secara terintegrasi di dalam ruang lingkup pengelolaan air limbah secara berkesinambungan. Oleh karena itu dibutuhkan sistem perpipaan yang tepat dan sesuai untuk mendukung suatu sistem pengelolaan limbah.

Berdasarkan latar belakang
permasalahan yang telah dipaparkan,
maka permasalahan yang dapat
dirumuskan yaitu, bagaimana
pra-rancangan sistem jaringan perpipaan
air limbah industri kerupuk kulit (krecek)
yang sesuai dengan memperhatikan
kondisi topografi di lapangan sehingga
dapat mengalir secara gravitasi menuju
IPAL?, bagaimana desain pipa serta
diameter pipa dalam sistem perpipaan


tersebut ?, berapa kebutuhan bak kontrol yang dibutuhkan serta desainnya ?, berapa rincian anggaran biaya (RAB) yang dibutuhkan dalam pra-rancangan sistem jaringan perpipaan air limbah tersebut?.

Penelitian ini bertujuan untuk merencanakan sistem jaringan perpipaan air limbah industri kerupuk kulit (krecek) yang sesuai dengan memperhatikan kondisi topografi di lapangan sehingga dapat mengalir menuju IPAL secara gravitasi, mengetahui desain pipa yang tepat serta menghitung diameter yang sesuai dengan kebutuhan debit air limbah dan kemiringan pipa, mengetahui kebutuhan bak kontrol yang dibutuhkan serta desainnya dengan memperhatikan kondisi di lapangan serta mengetahui Rincian Anggaran Biaya (RAB) dalam merancang sistem jaringan perpipaan air limbah industri kerupuk kulit (krecek).

Komposisi kimia kulit berbeda-beda tergantung dari jenis, bangsa, umur dan jenis kelamin. Kulit terdiri dari air, protein, lemak, karbohidrat, mineral, vitamin dan enzim. Komposisi kimia kulit segar terdiri dari $64 \%$ air, $33 \%$ protein, $2 \%$ lemak, $0,2 \%$ mineral dan $0,8 \%$ substansi lain. Dari $33 \%$ protein yang terkandung di dalam kulit terdiri dari 29\% kolagen, 0,3\% elastin, $0,2 \%$ keratin, $1 \%$ globulin dan albumin, $0,7 \%$ mucin dan mukoid (Soeparno dkk, 2011).

Limbah cair atau air buangan (waste water) adalah cairan buangan yang berasal dari rumah tangga, perdagangan, perkantoran, industri maupun tempat-tempat umum lainnya yang biasanya mengandung bahan-bahan atau zat-zat yang dapat membahayakan kesehatan atau kehidupan manusia serta mengganggu kelestarian lingkungan hidup (Asmadi dan Suharno, 2012).

Menurut Soeparman (2002), sistem penyaluran air limbah berdasarkan asal airnya dibagi dalam tiga sistem yaitu: sistem penyaluran terpisah (separate system), sistem penyaluran tercampur (combined system) dan sistem kombinasi.

Sistem penyaluran air limbah dipengaruhi oleh letak dan topografi daerah yang dilayani. Menurut Soeparman (2002), berdasarkan sistem pengalirannya, penyaluran air limbah dibagi menjadi 3 (tiga), yaitu :

1. Sistem gravitasi, sistem ini digunakan bila badan air berada di bawah elevasi daerah penyerapan dan memberikan energi potensial yang tinggi terhadap daerah pelayanan terjauh.

2. Sistem pemompaan, sistem pemompaan digunakan apabila elevasi badan air di atas elevasi daerah pelayanan.

3. Sistem kombinasi, sistem kombinasi digunakan apabila air limbah dari pelayanan dialirkan ke bangunan pengolahan dengan bantuan pompa/ reservoir.

Dalam ketentuan umum kecepatan aliran di dalam pipa 0,9 - $2 \mathrm{~m} /$ detik (SNI 03-7065- 2005). Karena apabila kecepatan lebih dari $2 \mathrm{~m} /$ detik bisa menimbulkan pukulan air yang besar dan menimbulkan kerusakan pada alat plambing.

Pada aliran dalam pipa juga berlaku hukum kontinuitas dimana debit yang masuk pada suatu pipa, sama dengan debit yang keluar pada pipa (Alamsyah, 2012). Maka diameter pipa dapat dihitung dengan persamaan sebagai berikut :

$$
A=Q / V
$$

Keterangan :

$$
\begin{aligned}
& \left.A=\text { Luas penampang..........( } \mathrm{m}^{2}\right) \\
& \mathrm{Q}=\text { Debit.......................... }\left(\mathrm{m}^{3} / \text { detik }\right) \\
& \mathrm{V}=\text { Kecepatan aliran............(m/detik) } \\
& \mathrm{D}=\text { Diameter pipa.............(m) } \\
& \text { Dengan: } \quad A=\pi / 4 \times D^{2} \\
& \text { Maka : } \quad \mathrm{D}=\sqrt{\frac{4 x A}{\pi}}
\end{aligned}
$$

Limbah akan mengendap pada dasar dari dinding pipa pembuangan setelah digunakan untuk jangka waktu lama. Di samping itu kadang-kadang ada juga benda-benda kecil yang sengaja atau 
tidak jatuh dan masuk ke dalam pipa. Semuanya itu akan menyebabkan tersumbatnya pipa, sehingga perlu dilakukan tindakan pengamanan. (Kementerian Kesehatan RI, 2011). Pada saluran pembuangan di halaman perlu dipasang bak kontrol. Untuk pipa yang ditanam dalam tanah, bak kontrol yang lebih besar akan memudahkan pekerjaan pembersihan pipa. Penutup bak kontrol harus rapat agar tidak membocorkan gas dan bau dari dalam pipa pembuangan. (Kementerian Kesehatan RI, 2011).

\section{METODE PENELITIAN}

Penelitian ini dikhususkan untuk membahas rancangan Instalasi Perpipaan dari sumber limbah menuju Instalasi Pengolahan Air Limbah (IPAL) industri kerupuk kulit yang beralamat di Dusun Cegokan, Wonolelo, Pleret, Bantul.

Penelitian ini dilakasanakan di Dusun Cegokan, Wonolelo, Pleret, Bantul yang telah dilaksanakan pada bulan September 2019.

Pengumpulan data primer antara lain:

1. Jarak antar sumber limbah.

2. Kemiringan lahan perencanaan.

3. Ketinggian setiap sumber limbah dan IPAL.

Adapun data sekunder yang digunakan antara lain :

1. Debit limbah

2. Peta wilayah

3. Jumlah industri

Pra-rancangan diawali dengan observasi di lapangan untuk mendapatkan data tentang titik koordinat masing-masing sumber limbah, elevasi lahan pra-rancangan, kemiringan lahan dan kondisi lahan yang tersedia.

Setelah mendapatkan data yang dibutuhkan kemudian dilakukan analisis tentang sistem jaringan perpipaan yang akan diterapkan. Hal ini dapat dilakukan dengan studi literatur dan identifikasi terhadap data observasi.
Penyusunan perancangan sistem jaringan perpipaan limbah cair industri kerupuk kulit diawali dengan latar belakang, tinjauan pustaka, diagram alir, gambar teknis instalasi sistem jaringan perpipaan, dan rencana anggaran biaya. Bagan alur pra - rancangan dapat dilihat pada bagian di bawah ini :

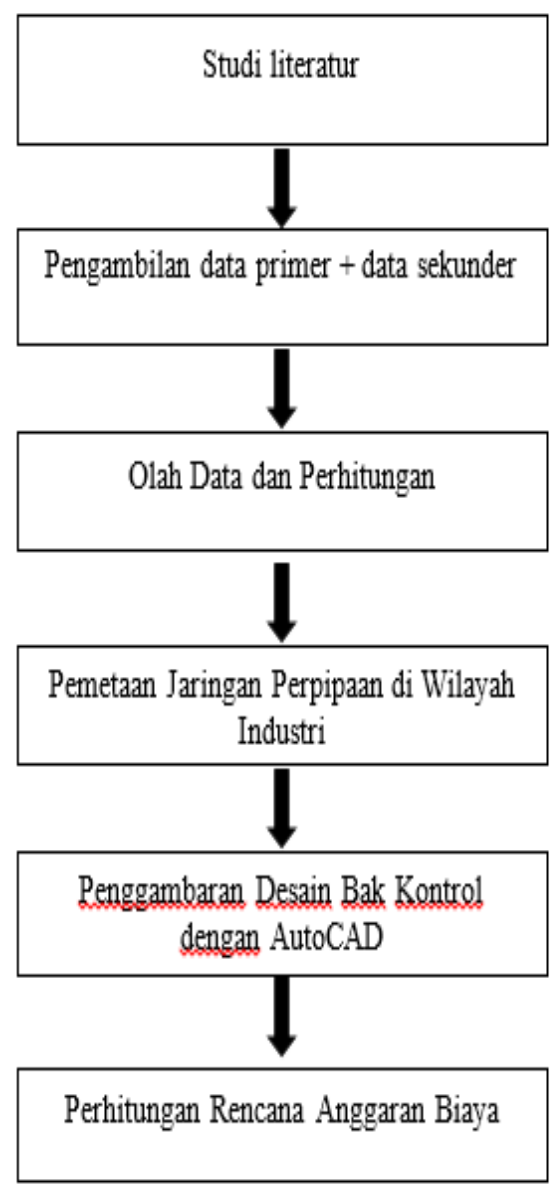

Gambar 1. Bagan Alur Pra-rancangan

\section{HASIL PENELITIAN DAN PEMBAHASAN}

Penentuan debit air limbah diperoleh dari penelitian terdahulu. Menurut (Prasetio, D, 2019) dalam penelitiannya dilakukan observasi mengenai fluktuasi air limbah dari debit air bersih yang digunakan setiap harinya. Selanjutnya dibuat grafik untuk mendapatkan peak 
flow. Berikut ini merupakan grafik debit limbah cair per hari dari proses pembuatan kerupuk kulit :

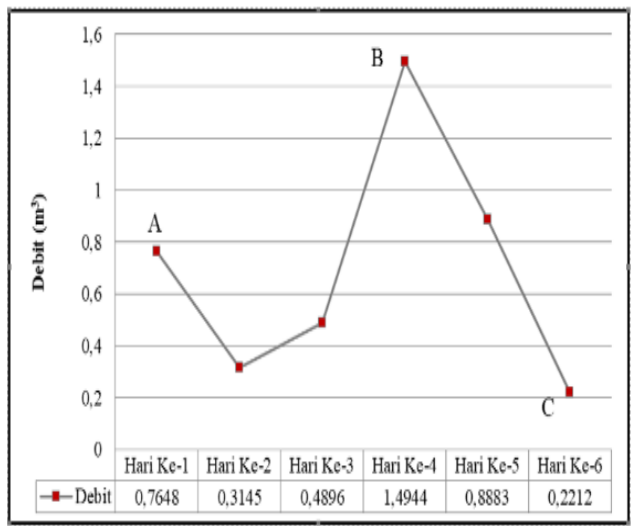

Gambar 2. Grafik Debit Limbah Per hari (Sumber : Data sekunder, 2019)

Berdasarkan grafik di atas, untuk menentukan debit air limbah dapat ditentukan dengan menggunakan titik tertinggi terbentuknya limbah yaitu pada hari keempat pengukuran dengan debit sebesar 1,4494 $\mathrm{m}^{3}$ per hari. Dari hasil tersebut maka jumlah debit harian dari kesebelas home industry yang berada di satu kawasan tersebut didapatkan debit harian sebagai berikut :

Debit keseluruhan

$=$ Peak Flow $\mathrm{x}$ jumlah rumah produksi

$=1,4944 \mathrm{~m}^{3} \times 11$ (jumlah total rumah produksi)

$=16,438 \mathrm{~m}^{3} /$ hari $=2,055 \mathrm{~m}^{3} / \mathrm{jam}(8 \mathrm{jam}$ kerja).

Elevasi lahan penelitian diukur menggunakan alat bantuan yaitu GPS (Global Positioning System). Pengukuran elevasi/ketinggian lahan dilakukan di titik IPAL dan di 11 home industry. Berikut data elevasi IPAL dan 11 home industry:

Tabel 1. Elevasi 11 Home Industry dan IPAL

\begin{tabular}{|c|c|c|}
\hline $\mathrm{N}$ & Lokasi & Elevasi/Ketinggian \\
$\mathrm{o}$ & & 86 \\
\hline 1 & $\mathrm{IPAL}$ & 87 \\
\hline 2 & Home Industry 1 & \\
\hline
\end{tabular}

\begin{tabular}{|c|c|c|}
\hline 3 & Home Industry 2 & 89 \\
\hline 4 & Home Industry 3 & 90 \\
\hline 5 & Home Industry 4 & 93 \\
\hline 6 & Home Industry 5 & 100 \\
\hline 7 & Home Industry 6 & 104 \\
\hline 8 & Home Industry 7 & 105 \\
\hline 9 & Home Industry 8 & 107 \\
\hline 10 & Home Industry 9 & 108 \\
\hline 11 & Home Industry 10 & 105 \\
\hline 12 & Home Industry 11 & 102 \\
\hline
\end{tabular}

(Sumber : Data primer, 2019)

Kemiringan lahan atau slope dihitung dengan cara perhitungan beda tinggi dan jarak antar sumber limbah dan IPAL. Kemiringan lahan atau slope dihitung dengan cara menyesuaikan jalur pipa yang akan melewati kesebelas home industry termasuk IPAL. Berikut data kemiringan lahan atau slope antar home industry dan IPAL serta jarak antar sumber limbah dan IPAL yang akan dilalui oleh pipa :

Tabel 2. Jarak dan Kemiringan Lahan

\begin{tabular}{|c|c|c|c|}
\hline $\begin{array}{c}\mathrm{N} \\
\mathrm{O}\end{array}$ & Lokasi & $\begin{array}{c}\text { Jarak } \\
(\mathrm{m})\end{array}$ & $\begin{array}{c}\text { Slope } \\
(\mathrm{m} / \mathrm{m})\end{array}$ \\
\hline 1 & Industri 1 - IPAL & 40 & 0,0025 \\
\hline 2 & $\begin{array}{c}\text { Industri 2 - } \\
\text { Industri 1 }\end{array}$ & 120 & 0,0016 \\
\hline 3 & $\begin{array}{c}\text { Industri 3 - } \\
\text { Industri 2 }\end{array}$ & 85 & 0,0011 \\
\hline 4 & $\begin{array}{c}\text { Industri 4 - } \\
\text { Industri 3 }\end{array}$ & 120 & 0,0025 \\
\hline 5 & $\begin{array}{c}\text { Industri 5 - } \\
\text { Industri 3 }\end{array}$ & 102 & 0,025 \\
\hline 6 & $\begin{array}{c}\text { Industri 6 - } \\
\text { Industri 5 }\end{array}$ & 350 & 0,0012 \\
\hline 7 & $\begin{array}{c}\text { Industri 7 - } \\
\text { Industri 6 }\end{array}$ & 140 & 0,0007 \\
\hline 8 & $\begin{array}{c}\text { Industri 8 - } \\
\text { Industri 7 }\end{array}$ & 80 & 0,0025 \\
\hline 9 & $\begin{array}{c}\text { Industri 9 - } \\
\text { Industri 8 }\end{array}$ & 99 & 0,001 \\
\hline 10 & $\begin{array}{c}\text { Industri 10 - } \\
\text { Industri 3 }\end{array}$ & 385 & 0,0038 \\
\hline 11 & $\begin{array}{c}\text { Industri 11 - } \\
\text { Industri 1 }\end{array}$ & 500 & 0,003 \\
\hline
\end{tabular}

(Sumber : Data primer, 2019)

Direncanakan pipa sambungan PVC tipe AW merupakan pipa yang menyalurkan air limbah dari home industry.

$Q=1,4944 \mathrm{~m}^{3} /$ hari $\quad 0,1868 \mathrm{~m}^{3} / \mathrm{jam}$ (8 jam kerja) 


$$
\begin{aligned}
& =0,1868 \mathrm{~m}^{3} / \mathrm{jam} \times 4=0,5604 \mathrm{~m}^{3} / \mathrm{jam} \\
& 0,0002 \mathrm{~m}^{3} / \text { detik }
\end{aligned}
$$

Dalam ketentuan umum kecepatan aliran di dalam pipa 0,9 - $2 \mathrm{~m} /$ detik (SNI 03-7065- 2005). Karena apabila kecepatan lebih dari $2 \mathrm{~m} /$ detik bisa menimbulkan pukulan air yang besar dan menimbulkan kerusakan pada alat plambing, jadi kecepatan aliran dalam pipa diasumsikan nilai $v=1 \mathrm{~m} /$ detik. Maka diameter pipa akan dapat diketahui dengan Persamaan:

$$
\begin{aligned}
\mathrm{A}= & \frac{Q}{V} \\
= & \frac{0,0002 \mathrm{~m}^{3} / \text { detik }}{1 \mathrm{~m} / \text { detik }} \\
= & 0,0002 \mathrm{~m}^{2} \\
\mathrm{D}= & \sqrt{\frac{4 \times 0,0002 \mathrm{~m}^{2}}{3,14}} \\
= & 0,055 \mathrm{~m}=2,16 \text { inci }=2,5 \text { inci (yang } \\
& \text { ada di pasaran). }
\end{aligned}
$$

Pipa sambungan digunakan untuk mengalirkan air limbah dari rumah industri ke bak kontrol kemudian dialirkan lagi menuju ke pipa utama. Jarak pipa sambungan dari rumah industri ke bak kontrol adalah sebagai berikut :

Tabel 3. Jarak pipa sambungan ke bak kontrol

\begin{tabular}{|c|c|c|c|}
\hline $\begin{array}{c}\mathbf{N} \\
\mathbf{0}\end{array}$ & Industri & Satuan & Jarak \\
\hline 1 & Industri 1 & $\mathrm{m}$ & 2 \\
\hline 2 & Industri 2 & $\mathrm{m}$ & 3 \\
\hline 3 & Industri 3 & $\mathrm{m}$ & 2 \\
\hline 4 & Industri 4 & $\mathrm{m}$ & 2 \\
\hline 5 & Industri 5 & $\mathrm{m}$ & 190 \\
\hline 6 & Industri 6 & $\mathrm{m}$ & 2 \\
\hline 7 & Industri 7 & $\mathrm{m}$ & 3 \\
\hline 8 & Industri 8 & $\mathrm{m}$ & 83 \\
\hline 9 & Industri 9 & $\mathrm{m}$ & 2 \\
\hline 10 & Industri 10 & $\mathrm{m}$ & 390 \\
\hline 11 & Industri 11 & $\mathrm{m}$ & 2 \\
\hline
\end{tabular}

(Sumber : Data primer, 2019)

Selanjutnya, setelah dari bak kontrol, pipa sambungan akan mengalirkan air limbah menuju ke pipa utama. Jarak setiap pipa sambungan yang menuju ke pipa utama sebagai berikut :

Tabel 4. Jarak pipa sambungan ke pipa utama

\begin{tabular}{|c|c|c|c|}
\hline No & Bak Kontrol & Satuan & Jarak \\
\hline 1 & Bak 1 & $\mathrm{m}$ & 4 \\
\hline 2 & Bak 2 & $\mathrm{m}$ & 6 \\
\hline 3 & Bak 3 & $\mathrm{m}$ & 4 \\
\hline 4 & Bak 4 & $\mathrm{m}$ & 4 \\
\hline 5 & Bak 5 & $\mathrm{m}$ & 6 \\
\hline 6 & Bak 6 & $\mathrm{m}$ & 4 \\
\hline 7 & Bak 7 & $\mathrm{m}$ & 250 \\
\hline
\end{tabular}

(Sumber : Data primer, 2019)

Selanjutnya dilakukan perhitungan untuk menentukan diameter pipa utama menggunakan persamaan kontinuitas. Maka didapatkan diameter pipa utama sebagai berikut :

$$
\begin{aligned}
\mathrm{A}= & \frac{Q}{V} \\
= & \frac{0,00057 \mathrm{~m}^{3} / \text { detik }}{1 \mathrm{~m} / \text { detik }} \\
= & 0,00057 \mathrm{~m}^{2} \\
\mathrm{D}= & \sqrt{\frac{4 \times 0,00057 \mathrm{~m}^{2}}{3,14}} \\
= & 0,07 \mathrm{~m}=2,76 \text { inci }=3 \text { inci (yang ada } \\
& \text { di pasaran). }
\end{aligned}
$$

Penanaman pipa dilakukan pada pipa sambungan. Pipa sambungan ditanam dikarenakan akan melewati jalan lokal. Pipa sambungan yang akan ditanam yaitu pipa sambungan yang akan menuju ke pipa utama. Kedalaman dan lebar galian pipa sambungan disesuaikan dengan kebutuhan dan diameter pipa sambungan. Berikut kedalaman dan lebar galian pipa sambungan :

Tabel 5. Kedalaman dan lebar galian pipa sambungan

\begin{tabular}{|c|c|c|c|}
\hline No & Pipa & $\begin{array}{c}\text { Kedalaman } \\
(\mathbf{m})\end{array}$ & $\begin{array}{c}\text { Lebar } \\
(\mathbf{m})\end{array}$ \\
\hline 1 & $\begin{array}{c}\text { Pipa } \\
\text { sambungan } \\
\text { industri } 4\end{array}$ & $<1$ & $<0,75$ \\
\hline 2 & $\begin{array}{c}\text { Pambungan } \\
\text { industri 6 }\end{array}$ & $<1$ & $<0,75$ \\
\hline 3 & $\begin{array}{c}\text { Pambangan } \\
\text { industri 9 }\end{array}$ & $<1$ & $<0,75$ \\
\hline
\end{tabular}

(Sumber : Data primer, 2019)

Bak kontrol berjumlah 7 unit. Bak kontrol direncanakan berada di atas 
permukaan tanah. Bak kontrol memiliki volume yang berbeda-beda disesuaikan dengan debit air limbah yang masuk. Berikut perhitungan volume bak kontrol :

\section{Besar volume}

$$
\begin{gathered}
\text { Keterangan }: V=\text { Volume } \\
\mathrm{Q}=\text { Debit } \\
\mathrm{Dt}=\text { Waktu tinggal }(15 \\
\text { menit }=0,25 \text { jam }) \\
\mathrm{S}=\text { Sisi }
\end{gathered}
$$

a. Bak untuk 1 industri

$$
\begin{aligned}
V & =Q \times d t \\
& =0,1868 \mathrm{~m}^{3} / \\
& =0,05 \mathrm{~m}^{3} \times \\
\%) & \\
& =0,06 \mathrm{~m}^{3} \\
\mathrm{~S} & =\sqrt[3]{0,06 \mathrm{~m}^{3}} \\
& =0,4 \mathrm{~m}
\end{aligned}
$$$$
=0,1868 \mathrm{~m}^{3} / \mathrm{jam} \times 0,25 \mathrm{jam}
$$$$
=0,05 \mathrm{~m}^{3} \times 1,2 \text { (over design } 20
$$

b. Bak untuk 2 industri

$$
\begin{array}{rl}
Q= & 0,1868 \mathrm{~m}^{3} / \mathrm{jam} \times 2=0,3736 \\
& \mathrm{~m}^{3} / \mathrm{jam} \\
V & \mathrm{Q} \times \mathrm{dt} \\
= & 0,3736 \mathrm{~m}^{3} / \mathrm{jam} \times 0,25 \mathrm{jam} \\
& =0,0934 \mathrm{~m}^{3} \times 1,2 \text { (over design } 20 \\
& \% \text { ) } \\
= & 0,112 \mathrm{~m}^{3} \\
\mathrm{~S}= & \sqrt[3]{0,112 \mathrm{~m}^{3}} \\
= & 0,48 \mathrm{~m}
\end{array}
$$

C. Bak untuk 3 industri

$$
\begin{array}{rl}
Q= & 0,1868 \mathrm{~m}^{3} / \mathrm{jam} \times 4=0,7472 \\
& \mathrm{~m}^{3} / \mathrm{jam} \\
\mathrm{V} & \mathrm{Q} \times \mathrm{dt} \\
= & 0,7472 \mathrm{~m}^{3} / \mathrm{jam} \times 0,25 \text { jam } \\
= & 0,1868 \mathrm{~m}^{3} \times 1,2 \text { (over design } 20 \\
& \% \\
= & 0,22416 \mathrm{~m}^{3} \\
\mathrm{~S}= & \sqrt[3]{0,22416 \mathrm{~m}^{3}} \\
= & 0,6 \mathrm{~m}
\end{array}
$$

2. Perhitungan volume

Bak kontrol direncanakan berbentuk persegi. Tebal dinding bak kontrol yang direncanakan adalah $10 \mathrm{~cm}=0,1 \mathrm{~m}$. Pekerjaan persiapan Pemasangan bouwplank:

$$
\begin{aligned}
& \text { a. Keliling bak untuk } 1 \text { industri } \\
& =2 \times(S+S) \\
& =2 \times(0,4 \mathrm{~m}+0,4 \mathrm{~m})=1,6 \mathrm{~m} \\
& \text { b. Keliling bak untuk } 2 \text { industri } \\
& =2 \times(\mathrm{S}+\mathrm{S}) \\
& =2 \times(0,48 \mathrm{~m}+0,48 \mathrm{~m})=1,92 \mathrm{~m}
\end{aligned}
$$

$$
\begin{aligned}
& \text { C. Keliling bak untuk } 4 \text { industri } \\
& =2 \times(\mathrm{S}+\mathrm{S}) \\
& =2 \times(0,6 \mathrm{~m}+0,6 \mathrm{~m})=2,4 \mathrm{~m}
\end{aligned}
$$

3. Pekerjaan bak kontrol

Pada pekerjaan bak kontrol, tidak dilakukan penggalian tanah, karena bak kontrol direncanakan berada di atas permukaan tanah.

\section{a. Beton bertulang}

Tabel 6. Volume beton bertulang

\begin{tabular}{|c|c|c|}
\hline No & Bak & $\begin{array}{c}\text { Volume } \\
\left(\mathrm{m}^{3}\right)\end{array}$ \\
\hline 1 & Bak 1 industri & 0,068 \\
\hline 2 & Bak 2 industri & 0,10384 \\
\hline 3 & Bak 3 industri & 0,172 \\
\hline
\end{tabular}

b. Tulangan beton (pembesian)

Tabel 7. Volume tulangan beton (Pembesian)

\begin{tabular}{|c|c|c|}
\hline No & Bak & $\begin{array}{c}\text { Volume } \\
\left(\mathrm{m}^{3}\right)\end{array}$ \\
\hline 1 & Bak 1 industri & 0,068 \\
\hline 2 & Bak 2 industri & 0,10384 \\
\hline 3 & Bak 3 industri & 0,172 \\
\hline
\end{tabular}

c. Bekisting/cetakan beton

Tabel 8. Volume bekisting/cetakan beton

\begin{tabular}{|c|c|c|}
\hline No & Bak & $\begin{array}{c}\text { Volume } \\
\left(\mathrm{m}^{2}\right)\end{array}$ \\
\hline 1 & Bak 1 industri & 1,36 \\
\hline 2 & Bak 2 industri & 2 \\
\hline 3 & Bak 3 industri & 3,2 \\
\hline
\end{tabular}

d. Plesteran dan acian

Tabel 9. Volume plesteran dan acian

\begin{tabular}{|c|c|c|}
\hline No & Bak & $\begin{array}{c}\text { Volume } \\
\left(\mathrm{m}^{2}\right)\end{array}$ \\
\hline 1 & Bak 1 industri & 1,52 \\
\hline 2 & Bak 2 industri & 2,23 \\
\hline 3 & Bak 3 industri & 3,56 \\
\hline
\end{tabular}

e. Pengecatan

Luas pengecatan = luas plesteran

Tabel 10. Luas pengecatan

\begin{tabular}{|c|c|c|}
\hline No & Bak & $\begin{array}{c}\text { Volume } \\
\left(\mathrm{m}^{2}\right)\end{array}$ \\
\hline 1 & Bak 1 industri & 1,52 \\
\hline 2 & Bak 2 industri & 2,23 \\
\hline 3 & Bak 3 industri & 3,56 \\
\hline
\end{tabular}

Selanjutnya dibuat gambar desain untuk setiap unit bak kontrol. Berikut gambar desain setiap unit bak kontrol :

1. Bak 1 industri 


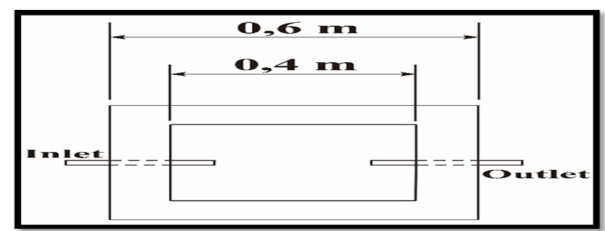

Gambar 3. Tampak atas bak kontrol 1 industri

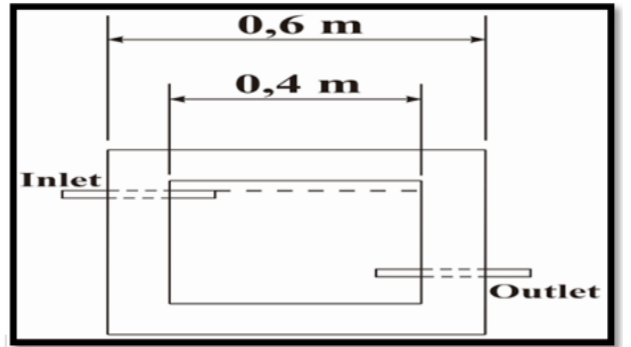

Gambar 4. Tampak samping bak kontrol 1 industri

2. Bak 2 industri

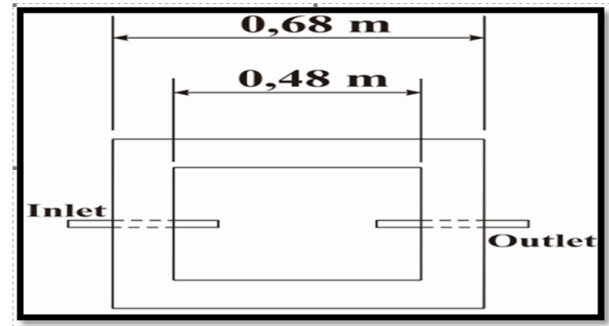

Gambar 5. Tampak atas bak kontrol 2
Gambar 6. Tampak samping bak kontrol 2 industri

3. Bak 4 industri

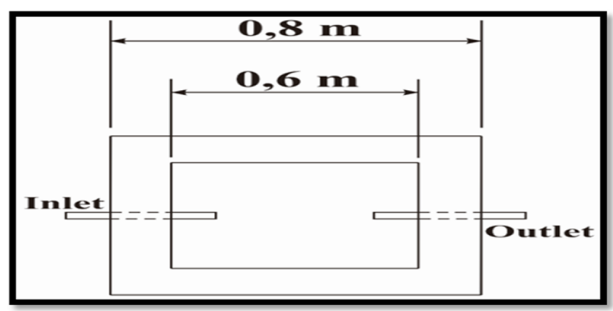

Gambar 7. Tampak atas bak kontrol 4 industri

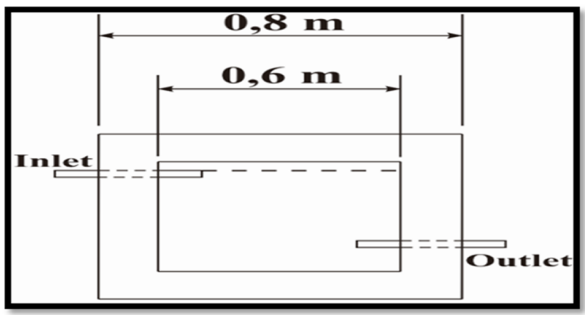

Gambar 8. Tampak samping bak kontrol 4 industri

Desain bak kontrol digambar menggunakan aplikasi AutoCad. Setelah itu dibuat gambar peta sistem jaringan perpipaan air limbah rumah industri Dusun Cegokan, Desa Wonolelo, Kecamatan
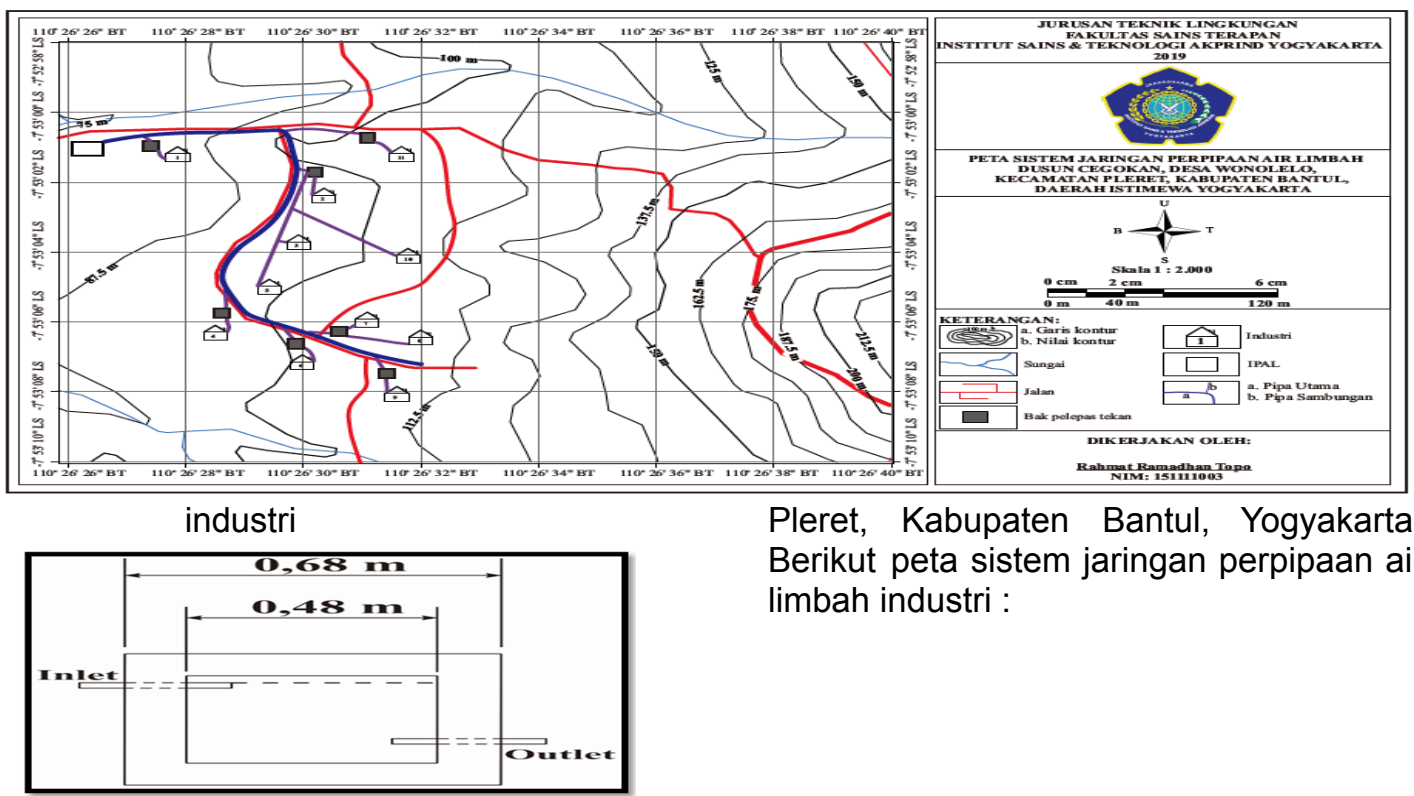

Pleret, Kabupaten Bantul, Yogyakarta Berikut peta sistem jaringan perpipaan air limbah industri :

Gambar 9. Peta sistem jaringan perpipaan air limbah industri 
Dari gambar 9, dapat dilihat peta sistem jaringan perpipaan air limbah yang direncanakan. Sistem pengaliran air limbah direncanakan mengalir secara gravitasi.

Pada setiap pipa yang akan masuk ke inlet bak kontrol dipasangkan stop kran berukuran 2,5 inci agar lebih mempermudah dalam perbaikan pipa jika sewaktu-waktu terjadi penyumbatan pada pipa. Stop kran berjumlah 7 buah dipasang pada 7 unit bak kontrol yang juga berfungsi agar memudahkan dalam pembersihan bak.

Pada gambar 9, direncanakan pipa utama ditempatkan mengikuti saluran drainase yang sudah ada menuju ke lokasi IPAL. Hal ini dilakukan agar mencegah pipa tidak mengganggu aktivitas di jalan lokal serta menghindari kerusakan pipa utama. Penempatan pipa utama yang mengikuti saluran drainase juga agar lebih mempermudah dalam pemasangan pipa serta meminimalisir anggaran biaya.

Setelah itu dilakukan Analisis Harga Satuan Biaya (AHSB) sistem jaringan perpipaan air limbah serta perhitungan Rencana Anggaran Biaya (RAB) yang mengacu pada ketentuan dari Peraturan Gubernur Daerah Istimewa Yogyakarta Nomor 40 Tahun 2018 Tentang Standar Harga Barang dan Jasa Daerah. Berikut analisis AHSB dan RAB Sistem Jaringan Perpipaan Air Limbah industri Dusun Cegokan, Desa Wonolelo, Kecamatan Pleret, Kabupaten Bantul, Yogyakarta :

Tabel 11. Analisis harga satuan sistem jaringan perpipaan air limbah

\begin{tabular}{|c|c|c|c|c|c|}
\hline \multirow[t]{2}{*}{$\begin{array}{l}\mathrm{N} \\
\mathrm{O}\end{array}$} & \multirow[t]{2}{*}{ Uraian } & \multirow[t]{2}{*}{ Satuan } & \multirow[t]{2}{*}{ Koefisien } & $\begin{array}{l}\text { Harga } \\
\text { Satuan }\end{array}$ & $\begin{array}{c}\text { Harga } \\
\text { Analisa }\end{array}$ \\
\hline & & & & (Rp.) & (Rp.) \\
\hline 1 & 2 & 3 & 4 & 5 & 6 \\
\hline \multirow[t]{7}{*}{1} & \multicolumn{5}{|c|}{ Pekerjaan Persiapan } \\
\hline & \multicolumn{5}{|c|}{ A. Pengukuran dan Perencanaan } \\
\hline & $\begin{array}{l}\text { Perenc } \\
\text { ana }\end{array}$ & $\mathrm{OH}$ & 1 & $\begin{array}{l}\text { Rp22.500,0 } \\
0\end{array}$ & $\begin{array}{l}\text { Rp22.500, } \\
00\end{array}$ \\
\hline & \multicolumn{4}{|c|}{ Total } & $\begin{array}{l}\text { Rp22.500, } \\
00\end{array}$ \\
\hline & \multicolumn{5}{|c|}{ Pemasangan Bouwplank } \\
\hline & $\begin{array}{l}\text { Kayu } \\
\text { Balok } \\
5 / 7 \\
\end{array}$ & $\mathrm{~m} 3$ & 0,012 & $\begin{array}{l}\text { Rp10.962.0 } \\
00,00\end{array}$ & $\begin{array}{l}\text { Rp131.544 } \\
, 00\end{array}$ \\
\hline & $\begin{array}{l}\text { Paku } \\
\text { biasa } \\
2 "-3^{\prime \prime}\end{array}$ & $\mathrm{kg}$ & 0,02 & $\begin{array}{l}\text { Rp20.000,0 } \\
0\end{array}$ & Rp400,00 \\
\hline
\end{tabular}

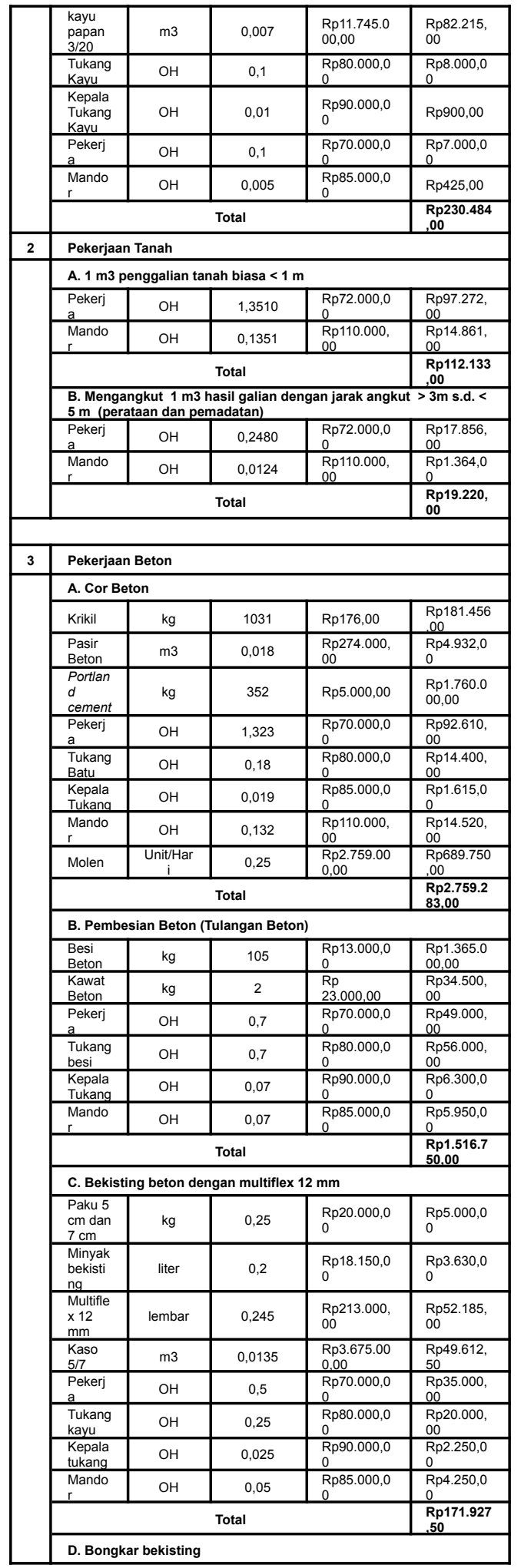




\begin{tabular}{|c|c|c|c|c|c|}
\hline & $\begin{array}{l}\text { Pekerj } \\
\mathrm{a}\end{array}$ & $\mathrm{OH}$ & 0,04 & $\begin{array}{l}\text { Rp70.000,0 } \\
0\end{array}$ & $\begin{array}{l}\text { Rp2.800,0 } \\
0\end{array}$ \\
\hline & Mando & $\mathrm{OH}$ & 0,004 & $\begin{array}{l}\text { Rp85.000,0 } \\
0\end{array}$ & Rp340,00 \\
\hline & \multicolumn{4}{|c|}{ Total } & $\begin{array}{c}\mathrm{Rp} 3.140,0 \\
0\end{array}$ \\
\hline 4 & \multicolumn{5}{|c|}{ Pekerjaan Pasangan } \\
\hline & \multicolumn{5}{|c|}{ A. Plesteran dan acian tebal $10 \mathrm{~cm}$} \\
\hline & $\begin{array}{l}\text { Portlan } \\
d \\
\text { cement }\end{array}$ & $\mathrm{kg}$ & 7,24 & Rp5.000,00 & $\begin{array}{l}\text { Rp36.200, } \\
00\end{array}$ \\
\hline & $\begin{array}{l}\text { Pasir } \\
\text { pasang }\end{array}$ & $\mathrm{m} 3$ & 0,014 & $\begin{array}{l}\text { Rp326.000, } \\
00\end{array}$ & $\begin{array}{l}\text { Rp4.564,0 } \\
0\end{array}$ \\
\hline & $\begin{array}{l}\text { Pekerj } \\
\text { a }\end{array}$ & $\mathrm{OH}$ & 0,3 & $\begin{array}{l}\text { Rp70.000,0 } \\
0\end{array}$ & $\begin{array}{l}\text { Rp21.000, } \\
00\end{array}$ \\
\hline & $\begin{array}{l}\text { Tukang } \\
\text { batu }\end{array}$ & $\mathrm{OH}$ & 0,15 & $\begin{array}{l}\text { Rp80.000,0 } \\
0\end{array}$ & $\begin{array}{l}\text { Rp12.000, } \\
00\end{array}$ \\
\hline & $\begin{array}{l}\text { Kepala } \\
\text { tukang }\end{array}$ & $\mathrm{OH}$ & 0,015 & $\begin{array}{l}\text { Rp85.000,0 } \\
0\end{array}$ & $\begin{array}{l}\text { Rp1.275,0 } \\
0\end{array}$ \\
\hline & $\begin{array}{l}\text { Mando } \\
r\end{array}$ & $\mathrm{OH}$ & 0,03 & $\begin{array}{l}\text { Rp85.000,0 } \\
0\end{array}$ & $\begin{array}{l}\text { Rp2.550,0 } \\
0\end{array}$ \\
\hline & \multicolumn{4}{|c|}{ Total } & $\begin{array}{l}\text { Rp77.589, } \\
00\end{array}$ \\
\hline & \multicolumn{5}{|c|}{ B. Pekerjaan pengecatan } \\
\hline & $\begin{array}{l}\text { Cat } \\
\text { Dasar } \\
\end{array}$ & $\mathrm{kg}$ & 0,1 & $\begin{array}{l}\text { Rp107.000, } \\
00\end{array}$ & $\begin{array}{l}\text { Rp10.700, } \\
00\end{array}$ \\
\hline & $\begin{array}{l}\text { Cat } \\
\text { Penutu } \\
\text { p }\end{array}$ & kg & 0,26 & $\begin{array}{l}\text { Rp107.000, } \\
00\end{array}$ & $\begin{array}{l}\text { Rp27.820, } \\
00\end{array}$ \\
\hline & $\begin{array}{l}\text { Kuas } \\
\text { Biasa } \\
\end{array}$ & buah & 0,5 & $\begin{array}{l}\text { Rp18.000,0 } \\
0\end{array}$ & $\begin{array}{l}\text { Rp9.000,0 } \\
0 \\
\end{array}$ \\
\hline & $\begin{array}{l}\text { Pekerj } \\
\text { a }\end{array}$ & $\mathrm{OH}$ & 0,02 & $\begin{array}{l}\text { Rp70.000,0 } \\
0 \\
\end{array}$ & $\begin{array}{l}\text { Rp1.400,0 } \\
0\end{array}$ \\
\hline & $\begin{array}{l}\text { Tukang } \\
\text { cat }\end{array}$ & $\mathrm{OH}$ & 0,063 & $\begin{array}{l}\text { Rp80.000,0 } \\
0\end{array}$ & $\begin{array}{l}\text { Rp5.040,0 } \\
0\end{array}$ \\
\hline & $\begin{array}{l}\text { Kepala } \\
\text { tukang }\end{array}$ & $\mathrm{OH}$ & 0,0063 & $\begin{array}{l}\text { Rp85.000,0 } \\
0\end{array}$ & Rp535,50 \\
\hline & $\begin{array}{l}\text { Mando } \\
\mathrm{r}\end{array}$ & $\mathrm{OH}$ & 0,003 & $\begin{array}{l}\text { Rp85.000,0 } \\
0\end{array}$ & Rp255,00 \\
\hline & \multicolumn{4}{|c|}{ Total } & $\begin{array}{l}\text { Rp54.750, } \\
50 \\
\end{array}$ \\
\hline 5 & \multicolumn{5}{|c|}{ Pekerjaan Jaringan Air } \\
\hline & $\begin{array}{l}\text { Pekerj } \\
\mathrm{a}\end{array}$ & $\mathrm{OH}$ & 4,06 & $\begin{array}{l}\text { Rp70.000,0 } \\
0\end{array}$ & $\begin{array}{l}\text { Rp284.200 } \\
00\end{array}$ \\
\hline & Tukang & $\mathrm{OH}$ & 3,4 & $\begin{array}{l}\text { Rp85.000,0 } \\
0\end{array}$ & $\begin{array}{l}\text { Rp289.000 } \\
.00\end{array}$ \\
\hline & $\begin{array}{l}\text { Kepala } \\
\text { Tukang }\end{array}$ & $\mathrm{OH}$ & 0,12 & $\begin{array}{l}\text { Rp90.000,0 } \\
0\end{array}$ & $\begin{array}{l}\text { Rp10.800, } \\
00\end{array}$ \\
\hline & $\begin{array}{l}\text { Mando } \\
\mathrm{r}\end{array}$ & $\mathrm{OH}$ & 0,125 & $\begin{array}{l}\text { Rp85.000,0 } \\
0\end{array}$ & $\begin{array}{l}\text { Rp10.625, } \\
00\end{array}$ \\
\hline & \multicolumn{4}{|c|}{ Total } & $\begin{array}{l}\text { Rp594.625 } \\
.00\end{array}$ \\
\hline
\end{tabular}

Tabel 12. Rencana anggaran biaya sistem jaringan perpipaan air limbah

\begin{tabular}{|c|c|c|c|c|c|}
\hline \multirow[t]{2}{*}{$\begin{array}{l}\mathrm{N} \\
\mathrm{O}\end{array}$} & \multirow[t]{2}{*}{ Uraian } & \multirow[t]{2}{*}{$\begin{array}{c}\text { Satua } \\
n\end{array}$} & \multirow[t]{2}{*}{ Volume } & $\begin{array}{c}\text { Harga } \\
\text { Satuan } \\
\text { dari } \\
\text { Analisa }\end{array}$ & $\begin{array}{l}\text { Jumlah } \\
\text { Harga }\end{array}$ \\
\hline & & & & (Rp.) & (Rp.) \\
\hline 1 & 2 & 3 & 4 & 5 & 6 \\
\hline \multirow[t]{4}{*}{1} & \multicolumn{5}{|c|}{ Pekerjaan Persiapan } \\
\hline & $\begin{array}{l}\text { a. } \\
\text { Pengukur } \\
\text { an dan } \\
\text { Perencan } \\
\text { aan } \\
\end{array}$ & $\mathrm{m} 2$ & 1,76 & $\begin{array}{c}\text { Rp22.500,0 } \\
0\end{array}$ & $\begin{array}{c}\text { Rp39.600,0 } \\
0\end{array}$ \\
\hline & $\begin{array}{l}\text { C. } \\
\text { Pemasang } \\
\text { an } \\
\text { bouwplank }\end{array}$ & $\mathrm{m}$ & 12,32 & $\begin{array}{c}\text { Rp230.484, } \\
00\end{array}$ & $\begin{array}{c}\mathrm{Rp} 2.839 .56 \\
2,88\end{array}$ \\
\hline & \multicolumn{4}{|c|}{ Total } & $\begin{array}{c}\text { Rp2.879.16 } \\
2,88\end{array}$ \\
\hline 2 & $\begin{array}{l}\text { Pekerjaan } \\
\text { bak } \\
\text { kontrol }\end{array}$ & & & & \\
\hline & $\begin{array}{l}\text { a.Penggali } \\
\text { an tanah } \\
\text { biasa }<1 \\
\mathrm{~m}\end{array}$ & $\mathrm{~m} 3$ & 3 & $\begin{array}{l}\text { Rp37.228,3 } \\
8\end{array}$ & $\begin{array}{l}\text { Rp111.685,1 } \\
4\end{array}$ \\
\hline & $\begin{array}{l}\text { b. Beton } \\
\text { bertulang }\end{array}$ & $\mathrm{m} 3$ & 0,62 & $\begin{array}{l}\text { Rp2.759.28 } \\
3,00\end{array}$ & $\begin{array}{l}\text { Rp1.710.75 } \\
5,46 \\
\end{array}$ \\
\hline & $\begin{array}{l}\text { c. } \\
\text { Pembesia } \\
\text { n }\end{array}$ & $\mathrm{m} 3$ & 0,62 & $\begin{array}{l}\text { Rp1.516.75 } \\
0,00\end{array}$ & $\begin{array}{l}\text { Rp940.385, } \\
00\end{array}$ \\
\hline
\end{tabular}

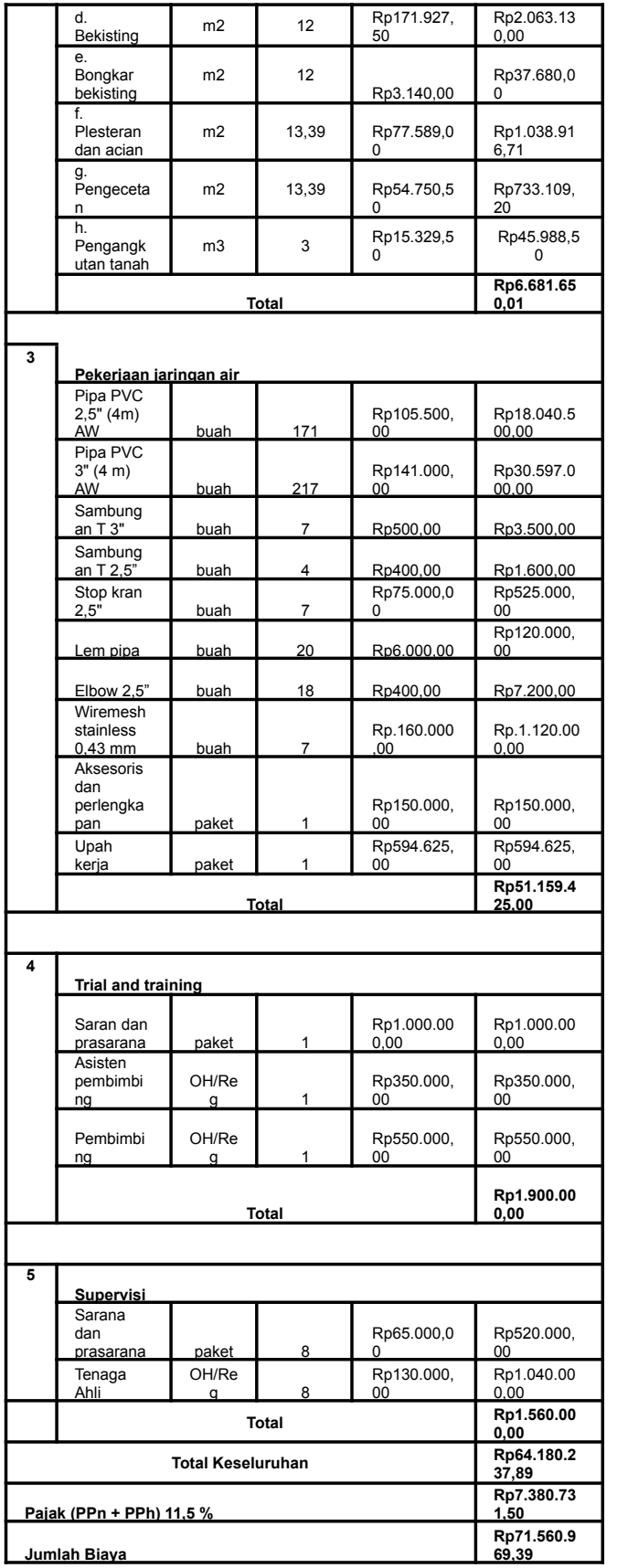

\section{KESIMPULAN}

Pertama, kondisi topografi pada daerah penelitian mendukung pengaliran limbah industri kerupuk kulit (krecek) secara gravitasi.

Kedua, hasil yang didapatkan dari pengukuran elevasi di lapangan 
menggunakan GPS (Global Positioning System) yaitu elevasi IPAL dan 11 industri yaitu : (IPAL $=86 \mathrm{mdpl}$, industri $1=87$ mdpl, industri $2=89 \mathrm{mdpl}$, industri $3=90$ mdpl, industri $4=93 \mathrm{mdpl}$, industri $5=100$ mdpl, industri $6=104 \mathrm{mdpl}$, industri $7=$ $105 \mathrm{mdpl}$, industri $8=107 \mathrm{mdpl}$, industri 9 $=108 \mathrm{mdpl}$, industri $10=105 \mathrm{mdpl}$, industri $11=102 \mathrm{mdpl}$ ).

Ketiga, diameter pipa utama dan pipa sambungan yang didapatkan dari hasil perhitungan menggunakan persamaan kontinuitas yaitu, Pipa yang digunakan yaitu pipa PVC jenis AW dengan panjang pipa utama $867 \mathrm{~m}$ dengan diameter 3 inci dan pipa sambungan berdiameter 2,5 inci.

Keempat, bak kontrol direncanakan berbentuk persegi dan berada di atas permukaan tanah yang berjumlah 7 unit bak. Bak kontrol untuk masing-masing 1 industri berjumlah 5 unit bak, meliputi : rumah industri 1 , rumah industri 4 , rumah industri 6 , rumah industri 9 dan rumah industri 11. Bak kontrol untuk 2 industri berjumlah 1 unit yaitu untuk rumah industri 7 dan 8. Bak kontrol untuk 4 industri berjumlah 1 unit bak yaitu untuk menampung limbah dari rumah industri 2,3,5, dan 10 .

Kelima, hasil dari perhitungan masing-masing bak kontrol didapatkan dimensi bak yaitu bak kontrol untuk 1 industri (panjang sisi $=0,4 \mathrm{~m}$, lebar sisi $=$ $0,4 \mathrm{~m}$, tinggi bak $=0,4 \mathrm{~m}$ ), bak kontrol untuk 2 industri (panjang sisi $=0,48 \mathrm{~m}$, lebar sisi $=0,48 \mathrm{~m}$, tinggi bak $0,48 \mathrm{~m}$ ) dan bak kontrol untuk 4 industri (panjang sisi $=$ $0,6 \mathrm{~m}$, lebar sisi $=0,6 \mathrm{~m}$, tinggi bak $=0,6$ $\mathrm{m})$.

Keenam, pada saluran pipa yang akan menuju ke bak kontrol dipasangkan stop kran berukuran 2,5 inci pada setiap pipa inlet yang akan masuk ke bak kontrol berjumlah 7 buah.

Ketujuh, hasil dari analisis harga satuan biaya dan perhitungan rencana anggaran biaya sistem jaringan perpipaan air limbah industry kerupuk kulit (krecek) Dusun Cegokan, Desa Wonolelo, Kecamatan Pleret, Kabupaten Bantul,
Yogyakarta, didapatkan jumlah biaya sebesar Rp. 71.560.969,39

\section{SARAN}

Pra rancangan sistem jaringan perpipaan air limbah yang telah dilaksanakan oleh peneliti dapat dijadikan sebagai referensi untuk pembangunan sistem jaringan perpipaan air limbah pada industri kerupuk kulit (krecek) agar limbah yang dibuang ke badan air tidak mencemari lingkungan.

Perlu dilaksanakan pemeliharaan rutin pada sistem jaringan perpipaan air limbah baik terutama pada saluran yang akan masuk ke bak kontrol.

Apabila terjadi kerusakan pada sistem jaringan perpipaan, perlu dilakukan perbaikan sesegera mungkin agar sistem tetap berjalan dengan efektif.

Pemerintah diharapkan dapat memberikan bantuan dana kepada pengusaha industri kerupuk kulit (krecek) untuk pembangunan sistem jaringan perpipaan air limbah.

\section{DAFTAR PUSTAKA}

Alamsyah, W. P, 2012, Perencanaan Kapasitas Ipa Jaringan Distribusi Air Bersih Di Kelurahan Pendingin Kecamatan Sanga -Sanga Kabupaten Kutai Kartanegara, Universitas 17 Agustus 1945 Samarinda.

Anonim: https://wonolelo.bantulkab.go.id/in dex.php/first, diakses pada 01 September 2019, Desa Wonolelo Kecamatan Pleret Kabupaten Bantul Provinsi D.I Yogyakarta.

Asmadi dan Suharno, 2012, Dasar-dasar Teknologi Pengolahan Air Limbah, Gosyen Publishing, Yogyakarta.

Kementerian Kesehatan RI (2011) Seri Sanitasi Lingkungan Pedoman Teknis Instalasi Pengolahan Air Limbah Dengan Sistem Biofilter Anaerob Aerob Pada Fasilitas Pelayanan Kesehatan.

Peraturan Gubernur Daerah Istimewa Yogyakarta Nomor 40 Tahun 2018 
Tentang Standar Harga Barang dan Jasa Daerah.

Prasetio, D, 2019, Pra Rancangan Instalasi Pengolahan Air Limbah (IPAL) Industri Kerupuk Kulit (Krecek) Dengan Sistem Kombinasi Anaerobic Baffled Reactor (ABR) dan Aerasi Lumpur Aktif, Jurusan Teknik Lingkungan, Fakultas Sains Terapan, Institut Sains dan Teknologi Akprind, Yogyakarta.

Soeparno, dkk, 2011, Dasar Teknologi Hasil Ternak, Gadjah Mada University Press, Yogyakarta.

SNI 03-7065- 2005. Tata Cara Perencanaan Sistem Plambing.

Soeparman dan Suparmin. 2002. Pembuangan Tinja dan Limbah Cair. Jakarta: UGC.

\section{BIODATA PENULIS}

Sri Hastutiningrum, S.T., M.Si., lahir pada tanggal 24 Mei 1958 di Yogyakarta, menyelesaikan pendidikan S1 pada Jurusan Teknik Kimia dari Universitas Pembangunan Nasional "Veteran" Yogyakarta tahun 1993 dan S2 pada Jurusan Kimia MIPA dari Universitas Gadjah Mada tahun 2006. Saat ini tercatat sebagai dosen tetap pada Jurusan Teknik Lingkungan di IST AKPRIND Yogyakarta dengan jabatan akademik Lektor pada bidang minat Mekanika Fluida, Teknologi Penyediaan Air, Sistem Jaringan dan Distribusi.

Hadi Prasetyo Suseno, S.T., M.Si., lahir pada tanggal 05 Oktober 1958 di Lampung, menyelesaikan pendidikan S1 pada Jurusan Teknik Kimia dari Institut Sains \& Teknologi
AKPRIND Yogyakarta tahun 1995 dan S2 pada Jurusan Kimia MIPA dari Universitas Gadjah Mada tahun 2005. Saat ini tercatat sebagai dosen tetap pada Jurusan Teknik Lingkungan di IST AKPRIND Yogyakarta dengan jabatan akademik Lektor pada bidang minat Rekayasa Lingkungan Industri, Satuan Operasi \& Satuan Proses, Produksi Bersih.

Rahmat Ramadhan Topo, lahir pada tanggal 9 januari 1998 di Luwuk Sulawesi Tengah, menyelesaikan pendidikan S1 pada Jurusan Teknik Lingkungan dari Institut Sains \& Teknologi AKPRIND Yogyakarta tahun 2020. 